\title{
Informing Citizens in a Highly Restrictive Environment Using Low-Budget Multimedia Communications: A Serbian Case Study
}

\author{
Aleksandar Spasic and Miloje Nesic \\ Association of Independent Electronic Media, Belgrade, Serbia
}

\section{a.spasic@computer.org mneshich@medianis.net}

\begin{abstract}
This paper describes an inexpensive network for news exchange between TV stations, as well as a system for news production and distribution in a highly restrictive environment developed by the authors, among others. The system was initially designed in response to the news restrictions established in Yugoslavia by Slobodan Milosevic. During this time, independent media were periodically disrupted or banning. All communication channels in Yugoslavia were controlled under the dictatorship and so were subject to being censored or even turned off. For this reason, the network had to provide high system redundancy. Following the democratic changes in Serbia, the project's mission evolved into a suitable solution for the network of branch offices. The network involves broadcasters and correspondents from the five successor countries of the former Yugoslavia. In addition, correspondents from other networks are now able to send their news packages and other information.
\end{abstract}

Keywords: News package, Multimedia information exchange, Multimedia communications, Low-Budget Multimedia, MPEG-4.

\section{Introduction}

Beginning in late 1980s, and formalized by the enactment of the restrictive Serbian Law on Public Information in 1998, the independent media in Serbia had been suppressed, persecuted, harassed and attacked by the former Yugoslav government led by Slobodan Milosevic. Using tactics, ranging from the bureaucratic takeover of media outlets, state-controlled broadcast-licensing competitions, to the brutal, still unsolved murder of independent newspaper editor Slavko Curuvija, the ruling regime created an environment hostile to the free press that alarmed human-rights groups around the world.

During this period, newspapers were seized, media outlets shuttered and journalists murdered. In response, the Association of Independent Electronic Media (hereinafter ANEM), the largest nongovernment radio and television net-

Material published as part of this journal, either online or in print, is copyrighted by the publisher of Informing Science. Permission to make digital or paper copy of part or all of these works for personal or classroom use is granted without fee provided that the copies are not made or distributed for profit or commercial advantage AND that copies 1) bear this notice in full and 2) give the full citation on the first page. It is permissible to abstract these works so long as credit is given. To copy in all other cases or to republish or to post on a server or to redistribute to lists requires specific permission and payment of a fee. Contact Editor@inform.nu to request redistribution permission. work in the former Federal Republic of Yugoslavia (now Serbia \& Montenegro) decided to develop a system for exchanging of news between TV stations the members of ANEM. The normal method for exchanging information, using expensive digital microwave transmitters, was not an option since due to the regime, ANEM's 
stations did not have the required financial resources.

The first decision of the ANEM's management was to establish the Technical Committee - an expert's body, aimed to do research and application of novel low-budget technologies to ANEM's stations. Several months before the Yugoslav federal elections on September 24, 2000, ANEM Technical Committee proposed a "Project on standardization of acquisition, information and communication systems in TV stations members of ANEM" (Nešić, Spasić, \& Jovanović, 2000). The project proposed the application of digital standards for video acquisition, non-linear video editing and communications in the local TV stations members of ANEM. This project offered a suitable solution for the exchange of news described in this paper.

To estimate the importance of such a system, two aspects have to be considered. The aspect related to the political constraints lies in the fact that the violent reactions of the regime against the media and citizens in the eve of democratic changes were real threat. Complete banning of free media and banning of public rallies were expected. Such action of the regime would have caused dramatic events, including clashes of police with citizens resulting in a number of injured or even dead. Dark forebodings related to the total suspension of the freedom of thought, expression and the press encouraged the ANEM's management to prepare its stations for forthcoming events.

The Technical Committee seriously faced the following assignment: establishing of a system for production and the exchange of urgent news, with high redundancy and capability to survive in a hostile political environment, using low-budget technical solutions.

The second important aspect was technical constraint. Basic user's demand was to provide production and the reliable exchange of news packages in broadcast quality. In accordance with BBC news standard norm, the duration of each news package is approximately one minute and $45 \mathrm{sec}-$ onds. Usual method for the exchange of video material between stations is by using the network of expensive microwave transmitters, but a lack of funds in the independent media as well as the state-controlled licensing of transmitting equipment excluded this solution. Other technical possibilities had to be considered, and there was nothing left for the Technical Committee to do but to propose using public communication services. Unfortunately, these services were ruined during the long period of sanctions and NATO bombing, and nothing but public telephony system was available. Very demanding user's requirements became more complex: a need for the reliable exchange of high-quality video (i.e. large video files) through devastated and state-controlled public telephony system, as fast as possible.

Because of constant financial exhausting, the independent local and regional TV broadcasters had to use the production equipment of customer instead of professional quality. That means that the production chain, from camcorders up to the consumer delivery system, consisted of analog components. Low budget influences to the low quality of equipment, resulting in the low quality of the final programme products. That was a reason why the project proposed the application of digital standards for video acquisition, non-linear video editing and communications in the local TV stations members of ANEM. Also, it is important to notice that former Yugoslavia was under the sanctions of UN Security Council for more than 8 years, and import of any professional equipment was a difficult task.

All the technologies applied in this project existed in infant forms. ISDN achieved its maturity, but it was available only in several cities in Serbia. DVCAM was declared semi-professional standard for video-acquisition and its application in a professional environment was under suspicion. The satellite internet connection service offered by Hughes Network Systems was expensive and it was proposed as a back-up solution. MPEG-4 was released in October 1998 as a draft international standard for the coding of audiovisual objects and it was aimed primarily at low bit rate video communications. During the 1999 it went through several refinements and the applica- 
tion of MPEG-4 compression standard in this project became one of the earliest attempts in using it in professional media environment.

Thanks to this system, the citizens of the biggest cities in Serbia had opportunity to see the events influenced on the fall of Milosevic's regime and to participate in "Serbian smooth revolution" that took place on October 5, 2000.

After democratic changes in Serbia, the system was re-designed and today it is the biggest network of news branch offices in South-Eastern Europe involving independent media and free lancers from five countries.

\section{Literature Review}

Multimedia has long played an important role in the process of informing activities: learning, studying, researching, and communicating. Professional media activities, such as production of news, are based on creation and transfer of multimedia content. In accordance with Zeng and $\mathrm{Yu}$ (1999), a news package is a special form of multimedia data, which can be managed in conformance with multimedia data management structure.

Television programme production process can be presented in a number of stages, and Drewery and Riley (1999) outlined a simplified production process. At a very high level the basic stages required to make and broadcast a programme are the same for all the constituent components, be it video, audio or presentation data. Hunter, Lau and White (2000) discussed relationships between stages and components in production process.

Ebner (2004) analyzes new business and production processes and production data flow description is presented. Massenzio and Ciferri (2003) discuss how a broadcast company structures its facilities, and describes the main areas in a common production and broadcasting environment.

The delivery of multimedia information demands a large amount of channel bandwidth. This demand becomes one of the major driving forces for the development of new network infrastructure. Sharda (1999) presented fundamentals and future directions of multimedia networks, including multimedia transmission requirements.

Thomas and Storey (1999) anticipated that "changes in the way content is produced will be driven by blend of changes in the style of consumption and advances in technology" and emphasized MPEG-4 as a successful standard for video compression. Digital video compression is a field in which fundamental technologies were motivated and driven by practical applications so that they often lead to many useful advances. Especially, MPEG, the most recognized standard for digital video compression, has enabled many successful digital-video applications. These applications range from digital-video disk (DVD) and multimedia CDs on a desktop computer, interactive digital cable television, to digital satellite networks. Nowadays, video compression technologies are being used in almost all modern digital video systems and networks. Not only is video compression equipment being implemented to increase the bandwidth efficiency of communication systems, but video compression also provides innovative solutions to many related videonetworking problems.

There exist various compression techniques that are in part competitive and in part complementary. Many of these techniques are already applied in industries, while other methods are still undergoing development or are only partly realized. Most relevant work in the standardization bodies concerning video coding is outlined by Tang and Jin (2002).

The MPEG-4 architecture signifies a major paradigm shift from earlier multimedia content representation standards. Much technical debate has focused on compression efficiency of the MPEG4 video coder and, to a lesser extent, on the efficiency of the audio coder. Koenen (2002) pre- 
Informing Citizens in a Highly Restrictive Environment

sented information related to the efficiency of these coders. Also, Rittermann and Schuldt (2003) emphasized the benefits of MPEG-4 application system.

The authors of this paper have been in charge of "Project on the standardization of acquisition, information and communication systems in TV stations members of ANEM" (Nešić, Spasić, \& Jovanović, 2000) which included the application of the above mentioned technologies.

\section{News Production Process}

\section{Traditional Approach}

Traditional production is based on analog processes and expensive analog components with no computers in the technological system, minimal using of the computers in the other parts of workflow and tape-based technological chain.

Segment production, in which primarily archival material is used to assemble the final program, has traditionally been characterized by organic workflows and extremely high quality output. It is built around analog processes that depend on expensive equipment located in expensive facilities. Media is edited and stored on magnetic tape, production tasks are strictly defined, and workflows are largely linear in nature.

Much of the same has been true for real time production environments. Except that in a nightly news or sports production studio, the production cycles are often razor thin. Material must be scripted, edited, and sent directly to air. Production systems in this environment are mission critical and, therefore, must be extremely stable and fault tolerant. Nonetheless, the workflows are still primarily linear and tape-based.

Hunter, Lau and White (2000) diagramed simplified chain of production (see Figure 1).

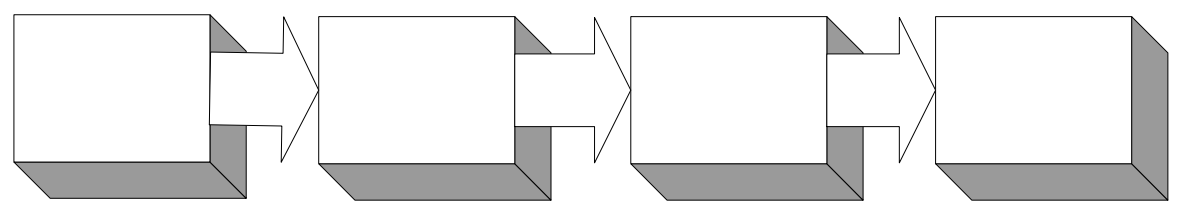

Figure 1: Simplified production chain

A news production process can be considered in a number of stages. A program's life begins with scheduling, research and planning. Video shots, audio clips and other program items are created during the acquisition stage. In this stage, archived material is also checked for immediate suitability for re-purposing. Next stage is editing, when shots, clips, animations and assembled items are put in order. After editing, program is sent to delivery point for transmission or play out. Finally, program is archived on tapes.

\section{New Model of News Production Process}

New technology represents both an opportunity and a challenge to the traditional television production market. The last ten years have brought about some fundamental changes in the basic workflows and business models of content creation in the television industry. The dividing line between offline and online editing is starting to erode. The linear workflows of tape-based production are fragmenting. Producers can now perform multiple tasks in parallel including media creation, editing, and compositing. The sequence is which production and post-production tasks occur is less important than it used to be. As a result, there is really no longer any "post" in post- 
production. These changes are placing unprecedented strain on traditional production workflows and many of them are beginning to collapse under the pressure.

The new model of production and post-production is based upon: digital formats, the centralized management of media and metadata, non-linear assembly of media elements, high-speed networks, format agnostic distribution and automated processes (locating footage, performing rough cuts, approvals, playout). Business processes are changed, each department is involved and processes are coming closer (Ebner, 2004).

Ubiquitous computers and IP networks are leading to: (1) increased democratization - proliferation of low-cost tools in studios and in the field, (2) increased decentralization - broadband networks make it possible to edit and publish anywhere, and (3) the process of online editing is eroding and offline editing is dominating.

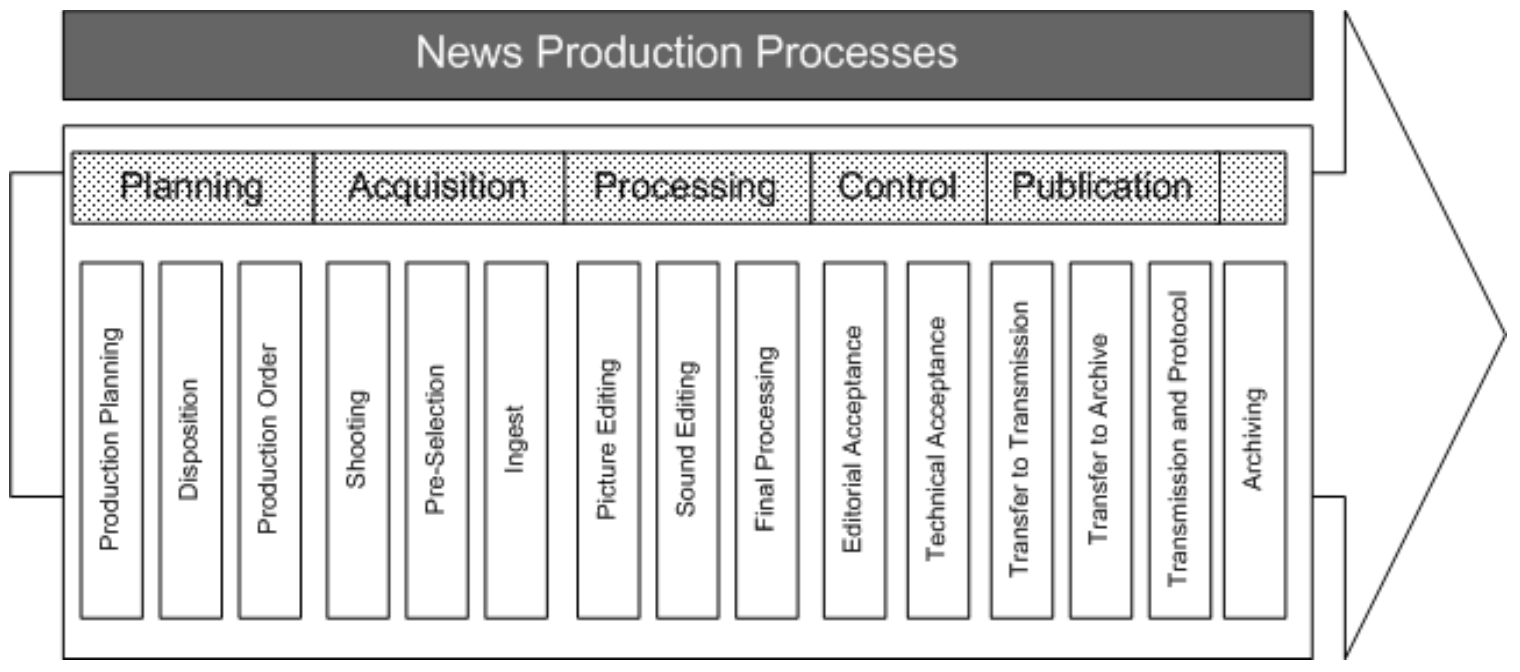

Figure 2: News Production Processes

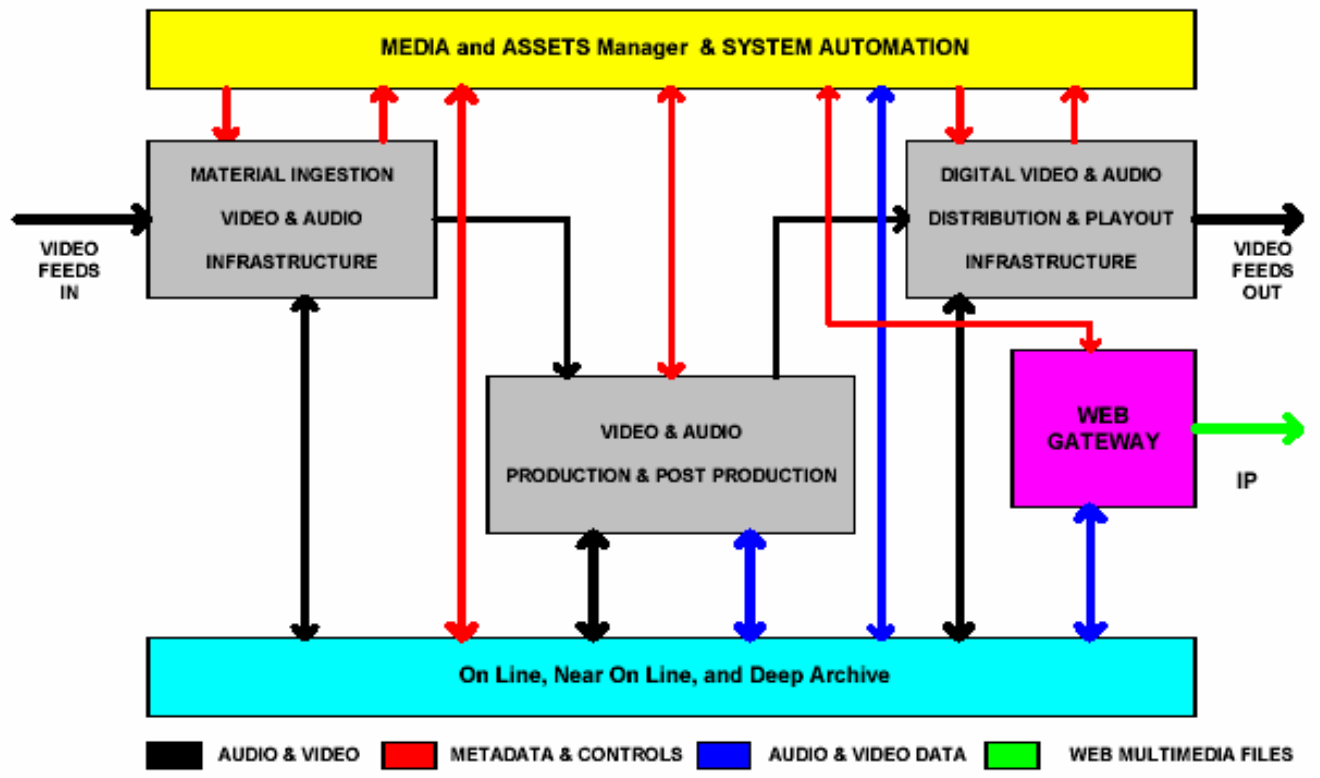

Figure 3: Main production areas in a modern TV facility 
Informing Citizens in a Highly Restrictive Environment

As content is one of the most valuable assets for broadcasting companies, ingesting, archiving, accessing, managing, delivering and security of digital content assets become basic requirements in the everyday life of multimedia producers and providers; at the same time, it becomes ever important the way the company structures its facilities, the processes involved and how it chooses the technologies that best adhere to the purpose related to content handling. The new production processes are shown on Figure 2.

Massenzio and Ciferri (2003) are describing the main areas in a common production and broadcasting environment and helping to summarize the media and control flow, as well as the main processes involved in a typical facility (see Figure 3).

\section{Restrictive Environment: Political, Organizational and Technical Issues}

\section{Political Constraints}

The independent media in Serbia - including radio and TV stations, printed media, agencies and media organizations - have been systematically exposed to various forms of persecution, pressures, blackmail and threats ever since the late ' 80 s. The everyday situation of independent media staff had for thirteen years been marked by persecution, media takeovers and clampdowns and an outflow of journalists who were either dismissed or, on their own, decided to leave their media houses turned into propaganda offices of the regime. Threats, public accusations and harassment all became commonplace. Representatives of independent grew accustomed to temporary arrests by the police, rigged trials, prison sentences, seizure of their private property, even the murders.

The independent media, radio and TV stations, dailies, weeklies, magazines and agencies were the essential and the strongest, if not the only segment of the democratic structure of the society. In addition to imparting information, they also played an important cultural and educational role since their example demonstrates the use of the basic postulates of the modern world - the freedom of thought, expression and the press - and indicate the violation of human rights and the need to protect these as well as to create a market economy and an open society.

Despite considerable repression, the independent media in Serbia played a key role in informing electors of the choices facing them in the federal election of September 24, 2000 and in the runup to the events of October 5.

\section{Relevant Events Preceded to "Serbian Smooth Revolution"}

In order to convey the unfolding of the sequence of events pertaining to the "Serbian smooth revolution", the extracts of the press coverage are presented in a chronological order. We have the opinion that this best illustrates the political situation in Serbia in those days when the first phase of project was launched.

\section{Sunday, September 24, 2000}

The Yugoslav federation, which is comprised of Serbia and Montenegro, holds its presidential election. This is the first time for more than 7 million eligible voters to decide whether President Slobodan Milosevic and the Socialist Party stay in power or whether his 13-year rule comes to an end. However, monitors report several irregularities that point to the opposition's fear that Milosevic will rig the election to hold on to power. The country has already kicked foreign media out of the country, stopped international observers from monitoring the election and banned opposition representatives from many polling stations or from inspecting voters' lists. Both sides claim victory. The ruling Socialist Party says it has 44 per cent of the vote, compared to 41 per cent for the Democ- 
ratic Opposition of Serbia, DOS. But the Opposition Leader Vojislav Kostunica says the DOS has captured 54 per cent of the vote, compared to 34 per cent for the government. Pre-election polls showed Milosevic trailing leading opposition candidate Kostunica. The counting of the ballets is suspended until Monday.

\section{Monday, September 25, 2000}

The opposition party claims victory despite the official release of the election results. About 40,000 people gather for a peaceful rally in Belgrade's main square to celebrate a victory for Kostunica and to say goodbye to Milosevic. The European Union releases a statement saying any claim to victory by Milosevic would be fraudulent, believing Kostunica won 57 per cent of the vote compared to 33 per cent for Milosevic. But final results are still not known.

\section{Tuesday, September 26, 2000}

The Yugoslav Federal Electoral Commission says that preliminary results show Kostunica won 48.22 per cent of the votes, just short of the 50 per cent minimum required needed to win the presidency. According to election rules, if no candidate wins a majority, a run-off election must be held within 15 days. It's scheduled for October 8. But opposition organizers say Kostunica won 60 per cent of the vote and Milosevic has only about 35 per cent, based on results from 60 per cent of polling stations. Milosevic ignores the pressure and refuses to accept defeat.

\section{Wednesday, September 27, 2000}

About 200,000 people protest against Milosevic in Belgrade with banners reading "He is finished" and "Time to go." The opposition rejects the idea of holding a run-off vote believing Kostunica won a clear majority. With counting of the ballots complete, Yugoslavia's electoral commission releases the final results, showing Kostunica with 48.96 per cent of the votes and Milosevic with 38.62 per cent.

\section{Thursday, September 28, 2000}

Milosevic confirms that a run-off election will be scheduled for October 8. The opposition threatens to hold a general strike unless Milosevic gives up his claim to a run-off vote and admit defeat. Democratic Party leader Zoran Djindjic told citizens to join in a "total boycott, a peaceful general strike." More protests like the one held in Belgrade on Tuesday are expected.

\section{Friday, September 29, 2000}

Strikes in Yugoslavia shut down businesses, coal mines and television broadcasts. Hundreds of taxi drivers blocked roads and bridges, and thousands of high school students walked out of class. The opposition files an official complaint with the Federal Election Commission and promise to take their fight to court if Kostunica isn't declared a winner.

\section{Saturday, September 30, 2000}

The Federal Election Commission rejects complaints made by the opposition. Disruptions continue with truckers shutting down an oil refinery by parking outside its main gates. Another rally is held in Belgrade. The opposition calls for a general strike on Monday.

\section{Sunday, October 1, 2000}

Russia releases a joint statement with Germany declaring "the will of the Serbian people in Yugoslavia had been clearly expressed" in the September 24 election. The statement is 
a clear call for Milosevic to step down. In an attempt to resolve the political crisis in Yugoslavia, Russia also sends in two envoys into Belgrade for talks.

\section{Monday, October 2, 2000}

Milosevic accuses the opposition of resorting to bribes and blackmail and says it is being controlled by NATO and Western countries. Truckers and taxi drivers slow traffic to a halt in several cities across the country by blockading roads and bridges. Walkouts at two important coal mines and an oil refinery have caused worries about the power and fuel supplies. Thousands of workers have left key industries such as railway lines idle. So far, Milosevic has not used either the military or the police to quiet calls for his departure.

\section{Tuesday, October 3, 2000}

The Milosevic government orders the arrest of 11 striking miners and two opposition leaders on suspicion of sabotage. The shut down of coal mines that supply power plants has left many parts of Serbia without electricity. The miners refused to go back to work after meeting with Yugoslavia's military chief of staff.

About 50,000 students march toward Milosevic's official residence in the suburb of Dedinje but riot police convince them to return to the centre of Belgrade. The government promises to take "special measures" against organizers involved in criminal activities.

\section{Wednesday, October 4, 2000}

Yugoslavia's highest court invalidates parts of the election although details as to which parts are annulled are not released. Kostunica warns the move may be "a big trap." If parts of the election must be repeated, it would buy Milosevic more time. Police take over key parts of a coal mining complex after attempting to break up the strike there, but miners and more than 10,000 supporters remain there. People begin to gather in Belgrade for a rally planned for tomorrow. The rally is expected to draw more than one million people.

\section{Thursday, October 5, 2000}

Dozens of people are injured in Belgrade as police and protesters fight with bullets, tear gas, batons and rocks. Protesters manage to storm several government offices, capture the state-run media and set fire to the parliament building. They destroy furniture and computers and throw pictures of Milosevic out the windows. Celebrations break out with singing and dancing in the streets after the police retreat from the area. Busloads of supporters arrive from across the country to join the mass rally. Now controlled by the opposition, news agencies declare Kostunica president. The opposition leader addresses the crowds, asking them to calm but remain in the streets overnight. Kostunica also calls for a meeting with military leaders and says a new federal parliament will convene Saturday. The news agencies reporting soldiers are staying in their quarters, refusing to take sides in the battle for power.

\section{Friday, October 6, 2000}

The European Union announces it will begin lifting international sanctions against Yugoslavia on Monday. Russian Foreign Minister Igor Ivanov meets with Milosevic at his official residence in Belgrade. Ivanov says Milosevic wants to continue playing a political role through his party. But both Russia and Milosevic's socialist allies in Montenegro have recently acknowledged Kostunica's September 24 election victory. Celebrations continue outside the legislative building in Belgrade. Kostunica meets with the army chief of staff Lieutenant General Nebojsa Pavkovic on Friday and had a one-hour conver- 
sation with Milosevic. He announces the people have nothing to fear of the army. Kostunica is set to be inaugurated on Saturday.

\section{The ANEM Story}

The Association of the Independent Electronic Media (ANEM) is the business association comprised of 28 radio stations and 16 television companies as well as of more than 60 affiliated organizations. ANEM was founded in 1993, and in 1997 it became a registered company in accordance with the Serbian Law on Companies.

According to the quantity of programme and service zones, ANEM members are big and small stations, local and regional. What is in common to all of them is - news broadcast programme that strives to achieve the highest professional standards. After October 5, 2000, around 100 radio and TV stations applied for membership into Association and some of them became affiliate members. Radio ANEM covers $60 \%$ of the territory of Serbia and $70 \%$ of the population. TV ANEM covers $35 \%$ of the territory of Serbia and $50 \%$ of the population.

The mission of ANEM is to establish a politically independent legal framework and an economically viable environment for the development of electronic media, and improvement of the professional and technical standards in the media sphere in order to meet the needs of the audience and serve the public interest in a proper way. During the ruling of Slobodan Milosevic ANEM was the fortress of Serbian independent journalism. Mainly consisted of radio and TV broadcasters owned by municipal authorities in biggest cities where democratic opposition had a power, ANEM organizationally was a network of independent electronic media.

\section{Technical Constraints}

Communication infrastructure in Serbia, especially public switched telephony system and terrestrial wireless systems, was significantly ruined during the long period of economical sanctions from 1992 up to 2000 - and NATO air strikes, 1999. The poor quality of public communication services was a major technical obstacle in the realization of system for exchange of news packages. The Integrated Services Digital Network (ISDN) connections in some cities were the best communication service available in that time.

ISDN was designed in the 1980s to provide data rates in the range of Kbps to Mbps over switched connections. To provide even higher data rates the original ISDN was extended to BroadbandISDN (B-ISDN). The ISDN services are provided to the user as ISDN interfaces, where each interface comprises a number of ISDN channels. ISDN channels, their bandwidths, and application areas are listed in Table 1 (Beyda, 1996, p. 211). These channels are combined to provide standard interfaces called: Basic Rate Interface (BRI), Primary Rate Interface (PRI), and Hybrid Interface. The various ISDN interfaces are listed in Table 2.

Table 1: ISDN Channels

\begin{tabular}{|c|c|c|l|}
\hline Channel Designation & Channel Type & Bandwidth & Application area \\
\hline A & Analog & $3-4 \mathrm{KHz}$ & Analog voice \\
\hline B & Digital & $64 \mathrm{Kbps}$ & Digitized voice and data \\
\hline C & Digital & $<16 \mathrm{Kbps}$ & Low speed data \\
\hline D & Digital & 16 or $64 \mathrm{Kbps}$ & Signaling or data \\
\hline
\end{tabular}


Informing Citizens in a Highly Restrictive Environment

Table 2: ISDN Interfaces

\begin{tabular}{|c|c|c|l|}
\hline Interface Name & Channels & Combined Bandwidth & Application area \\
\hline Basic-rate interface & 2B+D & $144-192 \mathrm{Kbps}$ & Digitized voice and data \\
\hline Primary-rate interface & 23B+D or 30B+D & $\begin{array}{c}1.544 \mathrm{Mbps} \text { or } 2.048 \\
\text { Mbps }\end{array}$ & $\begin{array}{l}\text { Multimedia including } \\
\text { video. LAN to LAN } \\
\text { connection }\end{array}$ \\
\hline Hybrid interface & $\mathrm{A}+\mathrm{C}$ & $\begin{array}{c}\text { Analog voice }+16 \mathrm{Kbps} \\
\text { data }\end{array}$ & $\begin{array}{l}\text { Hybrid connection for } \\
\text { transition period }\end{array}$ \\
\hline
\end{tabular}

TV stations that participated in the first phase of this project were located in the biggest cities in Serbia and they were selected depending of availability of ISDN connections in their cities. Also, the quality of Internet service providers (ISP) in these cities was considered as an important issue.

Basic-rate interface ISDN was the only acceptable connection available at that time-moment. The BRI interface is aimed at providing a simple interface to the desktop that includes a phone connection and a digital interface for the desktop computer. The D-channel is used for signaling; and the two B-channels provide a bandwidth of $128 \mathrm{Kbps}$ for data transmission.

Despite the conclusion that "the bandwidth of the BRI interface falls short for any serious multimedia application it is barely enough for low-end video conferencing" (Sharda, 1999, p.16), the authors of project had no other solution for communications.

\section{Choice of Standardized Compression Format}

The bandwidth required for a video signal in standard definition television is approx. $150 \mathrm{Mbps}$. Full format assumes horizontal resolution with 720 lines, vertical resolution with 576 lines and 25 frames per second. It is obviously that compression techniques had to be implemented on edited news package before the process of exchange starts.

The compression standard suggested for standard definition television was MPEG-2 (Sharda, 1999, p.12). MPEG-2 is a non-proprietary format that had been originally developed for transmission purposes, and is used by all new digital services, as well as DVD. Because MPEG-2 allows the use of motion compensated prediction, quite high compression ratios can be used. This makes MPEG-2 attractive for archiving and play-out because of server and LAN bandwidths could be reduced.

Unfortunately, BRI ISDN connection was the best available communication medium in Serbia in the middle of 2000. This was the main technical limitation and higher compression ratios than MPEG-2 had to be implemented. In accordance with the above mentioned, the application of MPEG-4 software compression was proposed solution.

MPEG-4 passed in 1998 as a standard for the coding of audiovisual objects. The "Moving Pictures Expert Group" is a working group of the International Organization for Standardization (ISO). Version 1 of MPEG-4 was approved in October 1998 and version 2 in December 1999. Three amendments to MPEG-4 Video have been published in 1999 and 2001.

In the early 1990s, MPEG-1 and MPEG-2 became two very successful standards for coding video with associated audio. MPEG-4 is not only an improvement of MPEG-2. Novel approaches to coding audio and visual content are defined. The way is to code it as audio, visual, or audiovisual objects in a $2 \mathrm{D}$ or $3 \mathrm{D}$ scene. The coding of these objects relates to their origin. Because of these many different processes defined in MPEG-4, it has become a very extensive norm. 
Initially, MPEG-4 was aimed primarily at low bit rate video communications. However, its scope was later expanded, and it became much more than a multimedia coding standard. MPEG-4 is efficient across a wide variety of bit rates ranging from a few Kbps to tens of Mbps (Liang, 1999, p.102). In addition to providing improved coding efficiency, MPEG-4 also provides a number of functionalities. Unlike MPEG-1 and MPEG-2, that were designed and, at least in the first phase, implemented as traditional hardware solutions, MPEG-4 was conceived as a standard whose implementation could be software.

The most important feature of MPEG-4, comparing with MPEG-2, is a higher compression ratio, which implies the lower size of news package file and a shorter transmission period. The other important features of MPEG-4, which influenced on choosing this standard as a data format suitable for the exchange of news packages, are the ability to efficiently encode mixed media data such as video, graphics, text, images, audio and speech, and error resilience to enable robust transmission of compressed data over noisy communication channels.

\section{Project Overview}

\section{System Overview: Phase I}

The system established in the first phase consisted of 8 completely configured workstations located in biggest stations members of ANEM. Each workstation had to provide autonomous work in video acquisition, non-linear digital video editing and the exchanging of news.

The locations and the list of participating stations are shown in Figure 4 and Table 3.

The parts of each workstation were the digital systems for collecting video information and nonlinear digital video editing and systems for communications.

The workstation consisted of the digital camcorder, digital tape, preview monitor, specially configured PC-based computer, a satellite antenna with a low-noise converter, ISDN public network connection and cabling. The heart of the workstation is a PC-based computer equipped with a non-linear digital video editing adapter card, a DirecPC ${ }^{\mathrm{TM}}$ adapter card for satellite internet connection and an ISDN network adapter. The workstation's block diagram is shown in Figure 5.

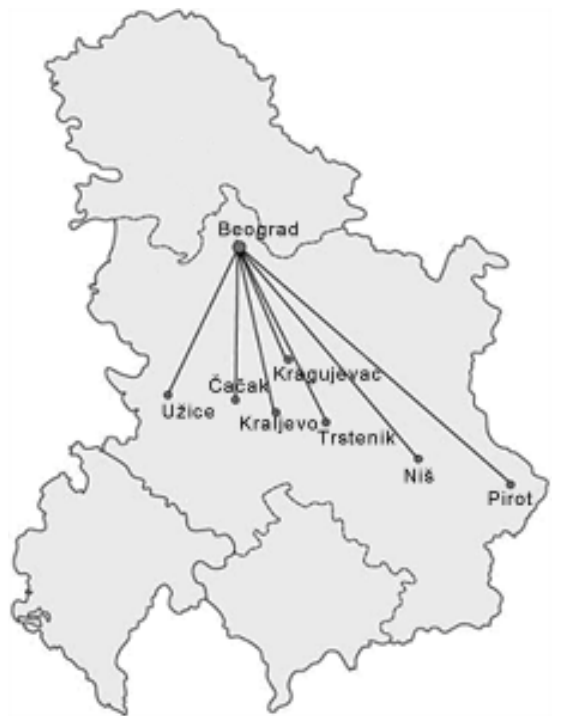

Figure 4: Locations of TV stations
Table 3: Participating TV stations in the first phase

\begin{tabular}{|l|l|c|l|}
\hline TV Station & Location & $\begin{array}{c}\text { Distance } \\
(\mathrm{km})\end{array}$ & $\begin{array}{c}\text { Connection } \\
\text { type }\end{array}$ \\
\hline $\begin{array}{l}\text { ANEM Central } \\
\text { Office }\end{array}$ & Belgrade & - & DSL, ISDN \\
\hline TV Nis & Nis & 240 & ISDN/DSL \\
\hline TV Kragujevac & $\begin{array}{l}\text { Kragu- } \\
\text { jevac }\end{array}$ & 140 & ISDN \\
\hline TV 5 & Uzice & 180 & ISDN \\
\hline TV Cacak & Cacak & 140 & ISDN \\
\hline TV Kraljevo & Kraljevo & 170 & ISDN \\
\hline TV Trstenik & Trstenik & 210 & ISDN \\
\hline TV Pirot & Pirot & 310 & ISDN \\
\hline
\end{tabular}




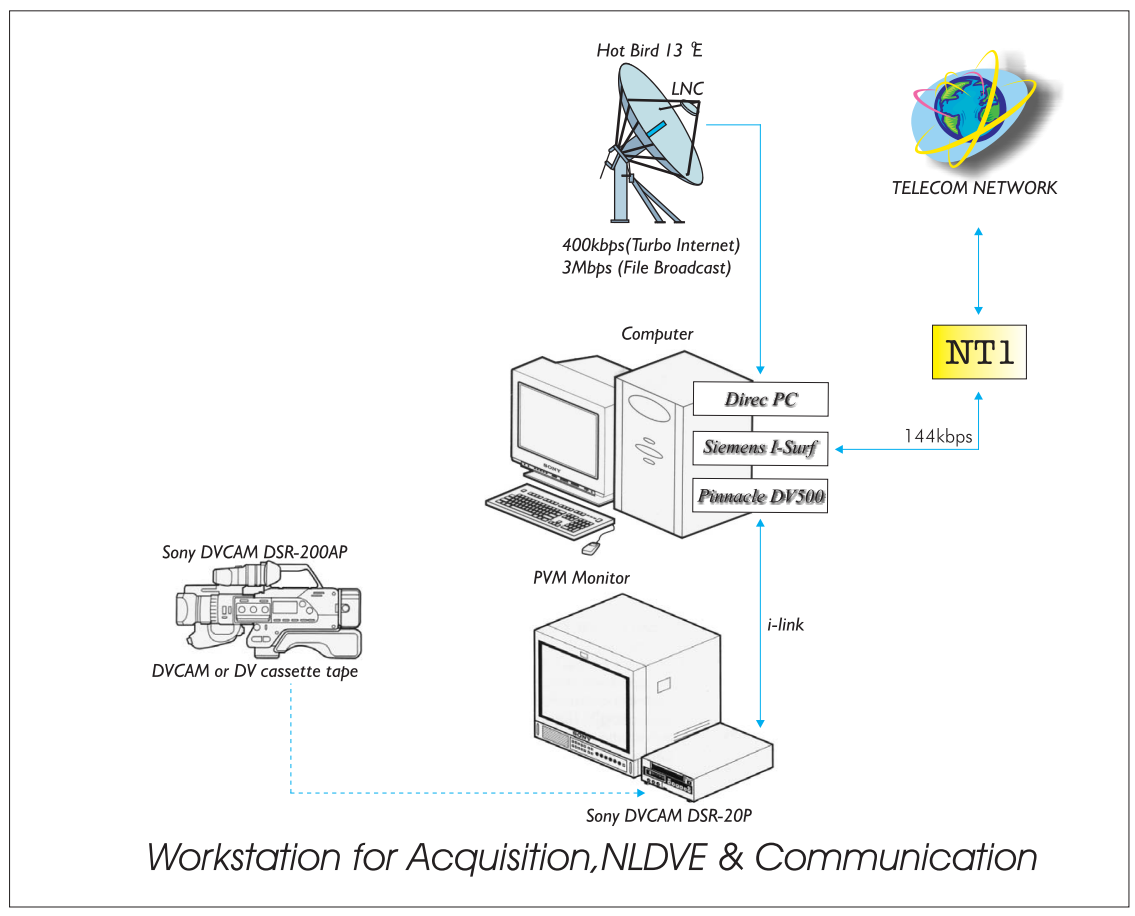

Figure 5: A Workstation for Acquisition, NLDVE \& Communication

\section{Package Contribution Methodology}

The news editing and package contribution methodology was as follows:

- Video information collected by the ENG team is transferred to the computer by FireWire (i-Link, IEEE 1394).

- Non-linear digital video editing (NLDVE) is made using the Pinnacle miro DV 500 adapter card and the suitable software (Adobe Premier).

- The package is compressed using the MPEG-4 software compressor.

- Public ISDN services and File Transfer Protocol are used for the transmission of the news package from the workstation station to the FTP Server computer located in the ANEM's Central Office.

The redundancy of the contribution subsystem is provided by the fact that the edited package can be sent from any computer equipped with the ISDN adapter to any FTP server.

\section{Package Distribution Methodology}

The package distribution methodology was as follows:

The satellite up-link station received the packages from an FTP server computer located on the ANEM's Central Office by the DirecPC ${ }^{\mathrm{TM}}$ adapter card which supports throughput up to 400 kbps in Turbo Internet mode or 3 Mbps in File Broadcast mode. 


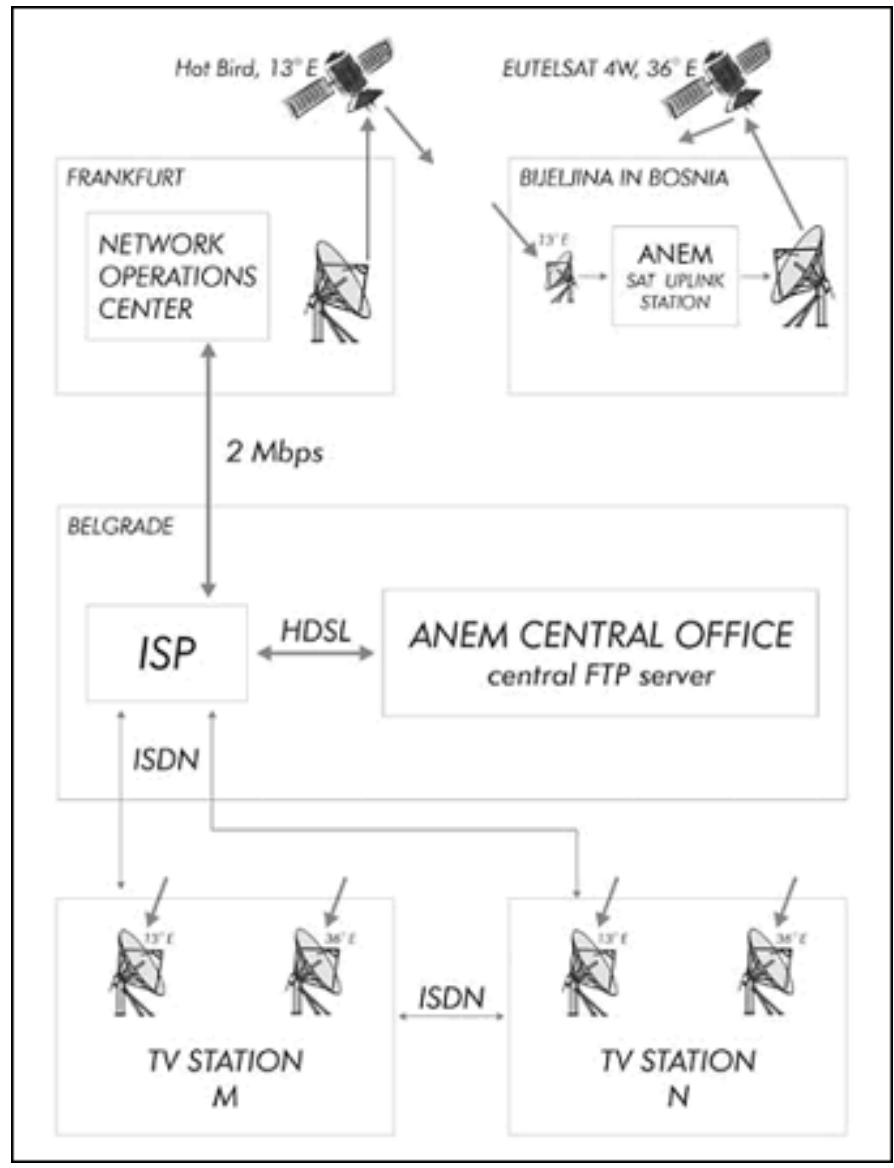

Figure 6: Package Distribution System Overview
All the TV stations, the members of ANEM, can receive all available news packages by using open satellite service from ANEM's digital channel located on satellite EUTELSAT $36^{\circ} \mathrm{E}$.

Among the other things, participated stations can use its own $\mathrm{Di}$ recPC ${ }^{\mathrm{TM}}$ system for receiving many packages from FTP server in ANEM Central Office if the open satellite service or satellite up-link station is not functioned. Using of this system was expensive, and it was a back-up system for package distribution.

It is assumed that each TV station can use its own ISDN connection for receiving the single package from the central FTP server.

Also, the TV stations can communicate directly, providing the horizontal redundancy of the system. Package distribution system overview is shown in Figure 6.

Two satellite services, internet service providers (ISP) and public

ISDN and HDSL services were combined for realization of package distribution methodology described above.

\section{Results in the First Phase}

A series of experiments with different resolutions and bit rates were conducted.

When the full quality of video material was requested, with standard horizontal and vertical resolution and frame rate, the duration of compression needed for one minute of the video material was approx. 4 minutes. One minute of such video material is transmitted for approx. 33 minutes. The quality of decompressed video material was quite acceptable for play-out.

In case when the horizontal resolution with 384 lines and vertical resolution with 288 lines was used, one minute of the video material was transmitted for approx. 10 minutes. The quality of decompressed video material was comparable with standard VHS video. This format was used when urgent news packages had to be transmitted, and lower transmission time was important.

\section{System Overview: Phase II}

The system was redesigned after the democratic changes in Serbia. Television B92 was established, the biggest and the most influential member of ANEM located in Belgrade, with national terrestrial covering and satellite covering. 


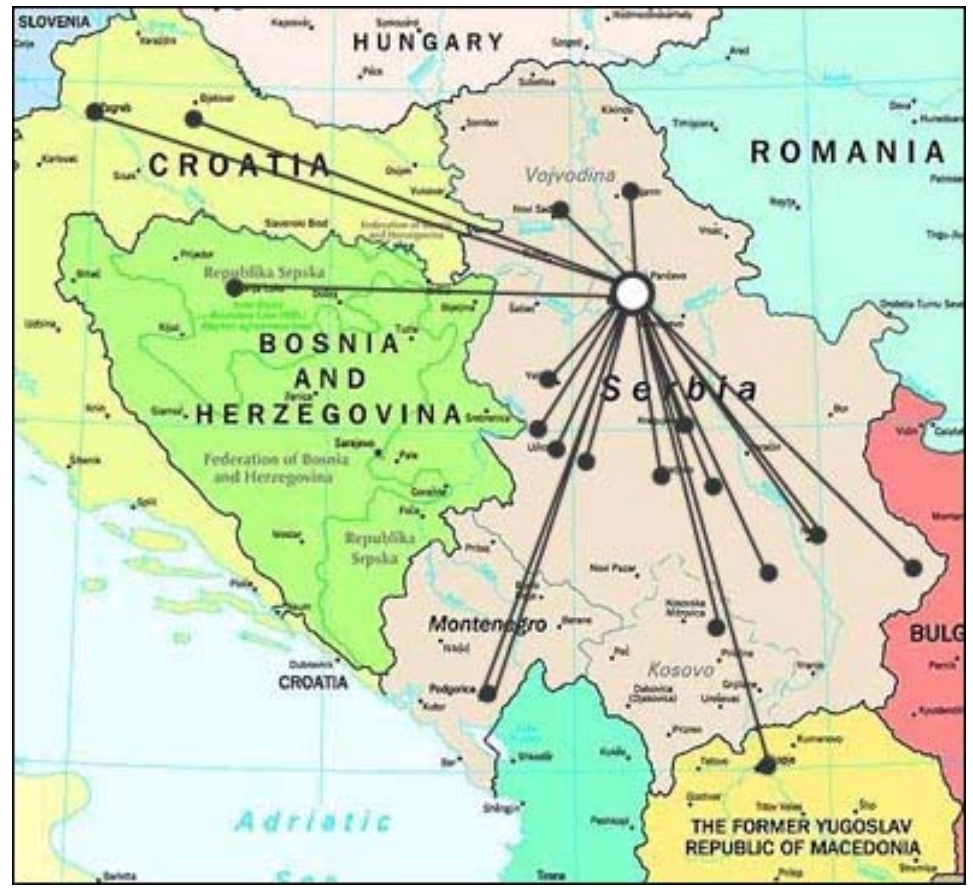

Figure 7: Branch Offices - Present Situation
The system today represents a network of news branch offices from local TV broadcasters in the biggest regional community centers in Serbia, as well as stations and branch offices from 5 neighboring countries to Radio Television B92. The locations and list of participating stations is shown on Figure 7 and Table 4.

The improvement of communication infrastructure in Serbia is in progress, offering new opportunities for exchanging of news packages and other multimedia content between stations in network. These opportunities include cable broadband, different DSL and wireless communications.

Thanks to hardware and software improvements, the duration of compression needed for one minute of the video material is today approx. one minute and 10 seconds. Nowadays, one minute of the compressed video material is transmitted for approx. 21 minutes over ISDN connection, and for approx. 2 minutes over DSL connection.

Table 4: Participating TV stations in second phase

\begin{tabular}{|c|c|c|c|}
\hline TV Station & Location & TV Station & Location \\
\hline 1. B92 (main) & Belgrade, Serbia & 11. TV Grk & Prokuplje, Serbia \\
\hline 2. $\quad$ TV Niš & Niš, Serbia & 12. Branch Office Niš & Niš, Serbia \\
\hline 3. TV Kragujevac & Kragujevac, Serbia & 13. RTV Kojot & Zrenjanin, Serbia \\
\hline 4. TV 5 & Užice, Serbia & 14. Glas juga & Gračanica, Serbia \\
\hline 5. TV Čačak & Čačak, Serbia & 15. TV Podgorica & Podgorica, Montenegro \\
\hline 6. TV Kraljevo & Kraljevo, Serbia & 16. NTV Montena & Podgorica, Montenegro \\
\hline $\begin{array}{ll}\text { 7. } & \text { TV Trstenik }\end{array}$ & Trstenik, Serbia & 17. PG Urbans & Novi Sad, Serbia \\
\hline 8. $\quad$ TV Pirot & Pirot, Serbia & 18. TV Skoplje & $\begin{array}{l}\text { Skoplje, FYR Mace- } \\
\text { donia }\end{array}$ \\
\hline 9. TV Valjevo & Valjevo, Serbia & 19. RTL Zagreb & Zagreb, Croatia \\
\hline 10. TV Požega & Požega, Serbia & 20. $\mathrm{CCN}, 7$ stations & Croatia \\
\hline & & $\begin{array}{l}\text { 21. VOA (Voice of Amer- } \\
\text { ica) }\end{array}$ & Washington, USA \\
\hline
\end{tabular}


It is obvious that a news package can be sent from any point on the globe with Internet connection and a suitable workstation. That is the reason why the system is easy to expand, and the future development of the system must consider that fact. With the growth of the system, the managing of news packages on the server will become a serious problem, and the development of content management workflow, as well as suitable software, have to be the next task.

\section{News Branch Office in Niš: An Example}

The corresponding branch office in Niš is a successor of offices established in the first phase of project. This office is the biggest and most important in the whole network in this time-moment.

Niš is a second largest city in Serbia and Montenegro, and the centre of the Administrative District of the Nišava. Situated at the crossroads, Niš connects the Balkans to Europe, and Europe to the Near East. As a traffic crossroad of European roads and railroads, together with an airport, it can easily be reached from all directions. Niš is a university centre, and a city of more than 350 000 inhabitants. It is the centre of the whole south-eastern part of Serbia - the natural, social, economic, educational, medical, cultural, and sports centre. The city covers the area of about 597 square kilometers, including the city of Niš itself, the Niška Banja spa and 68 suburbs. Among the other things, it is one of the most important industrial centers in Serbia and Montenegro.

The service zone of Branch office Niš consists of seven administrative districts located in southern and eastern Serbia with 1600000 inhabitants (see Figure 8). These districts are close to the possible sources of urgent information such is UN Security Zone in Kosovo (southern part of Serbia) or border crossings. The terrestrial covering of TV B92 is about 1200000 inhabitants in same area.

In addition to television news, the Branch office in Niš is capable of producing radio news packages, interviews, documentary production as well as news for the internet site of B92 (www.b92.net).

The branch office crew consists of one journalist and one technical operator. The journalist is responsible for planning and scripting package, disposition and presenting. The operator is responsible for shooting in the field, ingesting raw material into the editing computer, picture and sound editing, final processing and transfer to a server located in TV B92. The start-time of the crew is 30 minutes. The time needed for shooting is approx. 2 hours, and the additional 45 minutes are necessary for non-linear editing. That means that one package can be produced for approx. 3 hours and 45 minutes, including 30 minutes for transferring to the server. If the shooting location is outside of city of Niš, the time for two-way transportation must be added.

The Branch office in Niš is based on digital standards and represents an upgraded component of the previously described system. This upgrade is shown in the ability of faster sending and better quality of produced news packages.

Since B92 accepted DVCAM as a standard for news production, the Branch office in Niš has the equipment based on this standard. The equipment for non-linear digital video editing is based on the accelerator card Canopus DVStorm2 Pro.

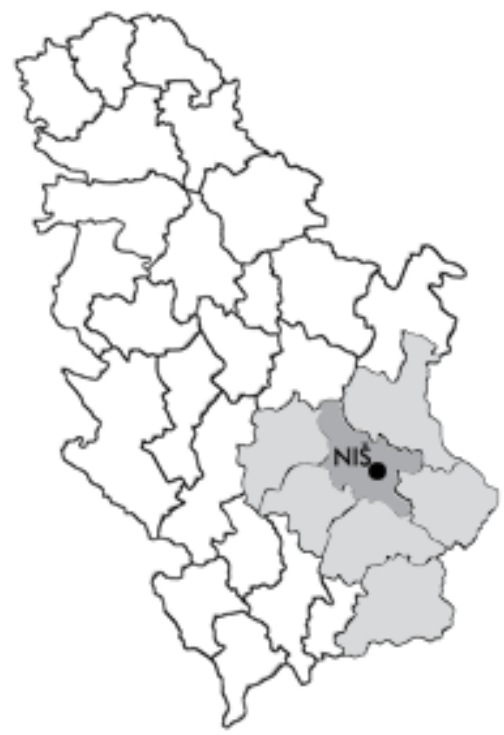

Figure 8: Office Niš Service Zone 
Informing Citizens in a Highly Restrictive Environment

The cable broadband communication is used for transferring the news packages and throughput is no less than $512 \mathrm{Kbps}$. The quality of communication channel made possible the exchange of news packages in full broadcast quality. The requirement for such quality assumes using of MPEG-2 compression and the bit rate of $6 \mathrm{Mbps}$. A file with one minute of compressed news material is approx. $45 \mathrm{MB}$ in size, and one news package is in average $80 \mathrm{MB}$ in size. The time needed for transmission of such package is approx. 22 minutes.

In situation when urgent news has to be exchanged, MPEG-4 compression would be used. In this case, one minute of news package is approx. $20 \mathrm{MB}$ in size. The news package is in average 35 $\mathrm{MB}$, and time needed for transmission is approx. 10 minutes.

The Branch office in Niš exists for one year, and this concept of branch office demonstrates that the presented system is economically viable and stable for use in the production of daily news.

\section{Conclusion}

A system for production and exchange of news packages, reliable and available for low-budget local TV broadcasting stations is considered in this paper.

The Metcalfe's law states that the value of a communication system grows approximately as the square of the number of users of the system $\left(N^{2}\right)$. Since a single user cannot connect to itself, the actual calculation is $N(N-1)$, or $N^{2}-N$. First formulated by Robert Metcalfe in regard to Ethernet, The Metcalfe's law explains many of the network effects of communication technologies and networks such as the Internet and World Wide Web.

Brinkman and Flank (2002) paraphrased the Metcalfe's law and stated that "the value of any media asset increases by the factor of the number of people with access to it." In addition to the above mentioned conclusion, the value of the news media asset in a professional media environment has another dimension - the delivery time. One of the most important advantages possessed by the low-budget television is the ability to be on the field where and when important events happen. This advantage increases in accordance with the Metcalfe's law if the functional and high-effective network of low-budget station is already established.

The contemporary multimedia solutions give the opportunities for building such an inexpensive network.

The project described in this paper was implemented in a highly restrictive environment. Political, financial and especially technical limitations strongly influenced on used standards and methodologies. It includes one of the earliest applications of MPEG-4 standard in a professional media environment.

Two aspects related to the influence of environment are considered in this paper. The first aspect shows political constraints and elucidates specific political situations and threats that independent media in Serbia had to confront. The everyday situation of independent media staff had for thirteen years been marked by harassment, and solutions for exchange of news had to provide redundancy of system and to anticipate hostile actions of the regime. Despite considerable repression, the independent media in Serbia played a key role in informing citizens and strongly demonstrated the use of the basic postulates of the modern world - the freedom of thought, expression and the press.

Technical limitations caused by poor communication infrastructure were the second important aspect for consideration. Despite accordance with information obtained from the different papers that some of the applied solutions fall short for any serious professional multimedia application, the authors of this project concluded that the solutions used and described in this case study are 
definitely better than no solutions at all. Fortunately, everyday usage of the proposed solutions proved that system is stable and viable.

After the democratic changes in Serbia, the system is redesigned and today it represents the biggest network of corresponding offices and television stations in South-Eastern Europe.

The challenge for the future is to make presented system economically viable and stable for use in volume TV production. The incremental growth of the system and involving other ANEM stations and corresponding offices from different countries offers new possibilities in informing citizens.

With the growth of the system, managing of news packages on the server will become serious problem, and the development of content management workflow, as well as suitable software, have to be the next task.

In this way, the web-based content management system is being planed to be developed. Designing the system for management and the production of metadata related on video material can make possible a strategy for the effective management of news media products and the data associated with them throughout their lifecycle.

\section{References}

Beyda, W. (1996). Data communications: From basics to broadband. Upper Saddle River, NJ: Prentice Hall.

Brinkman, S., \& Flank, S. (2002). Drinking from the fire hose: Managing metadata. Retrieved July 20, 2004 from http://www.broadcastpapers.com/asset/IBCeMotionFireHose.pdf

Drewery, J. O., \& Riley, J. L. (1999). The management and automatic production of metadata. Retrieved April 10, 2003 from http://www.bbc.co.uk/rd/pubs/papers/pdffiles/ibc99jod.pdf

Ebner, A. (2004). ARD/ZDF regelwerk fernsehproduktion (production data model). Retrieved September 15, 2004 from http://www.irt.de/IRT/mxf/activities/2004-02-04-IRT+ARD+ZDF-Ebner.pdf

Hunter, J. R., Lau, H., \& White, D. J. (2000). Enhanced television service development. Retrieved September 04, 2003 from http://www.bbc.co.uk/rd/pubs/papers/pdffiles/ibc00jh.pdf

Koenen, R. H., (2002). MPEG-4, or Why efficiency is much more than just a compression ratio. Retrieved from http://www.broadcastpapers.com/sigdis/ IBCIntertrustMPEG4CompressionRatio.pdf

Liang J. (1999). New trends in multimedia standards: MPEG4 and JPEG2000, Informing Science Special Issue on Multimedia Informing Technologies Part 2, 4, 101-106. Retrieved June 10, 2003 from http://inform.nu/Articles/Vol2/v2n4p101-106.pdf

Massenzio, M., \& Ciferri, F. (2003). Media management and digital archiving for a modern production workflow. Retrieved July 20, 2004 from http://www.broadcastpapers.com/asset/BCA03SHSMediaManagement.pdf

Nešić, M., Spasić, A., \& Jovanović, M. (2000). Idejni projekat standardizacije akvizicionih, informatičkih $i$ komunikacionih sistema lokalnih televizijskih stanica članica ANEM-a, (in Serbian) Ref.No: ANST 001/00-08, Belgrade: ANEM Technical Committee

Rittermann, M., \& Schuldt, M.,(2003). 3D television production based on MPEG-4 principles. Retrieved July 20, 2004 from http://wscg.zcu.cz/wscg2003/Papers_2003/D11.pdf

Sharda, N. (1999). Multimedia networks: Fundamentals and future directions, Communications of AIS, 1 , 1-34. Retrieved June 10, 2003 from http://cais.isworld.org/articles/1-10/article.pdf

Tang, Q., \& Jin, J. S. (2002). Compressed video transmission over digital networks: Analysis and design. Retrieved August 30, 2004 from http://crpit.com/confpapers/CRPITV22Tang.pdf 
Thomas, G., \& Storey, R. (1999). TV production in the year 2005. Retrieved April 10, 2003 from http://www.bbc.co.uk/rd/pubs/papers/pdffiles/mntx99gat.pdf

Zeng, W., \& Yu, H. (1999). Informing clientele through networked multimedia information systems: Introduction to the special issues volume 2 no. 4 and volume 3 no. 1. Informing Science Special Issue on Multimedia Informing Technologies Part 1, 2 (4), 83-86. Retrieved June 10, 2003 from http://inform.nu/Articles/Vol2/v2n4p83-86.pdf

\section{Biographies}

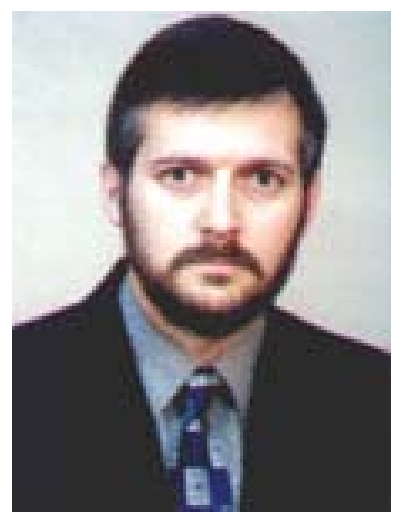

Aleksandar J. Spasic is the co-founder and member of the Technical Committee of the Association of Independent Electronic Media and visiting professor on School of Journalism in Novi Sad, Serbia. He teaches computers and software applications in television and Internet searching techniques for journalists. He received BSc and MSc degree in Computer Science from the Faculty of Electronic Engineering in Nis, Serbia. He is working on his $\mathrm{PhD}$ dissertation in the field of software-intensive television production.

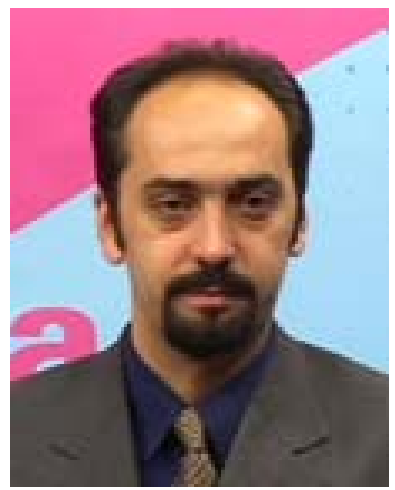

Miloje S. Nesic is the co-founder and the acting chairman of the Technical Committee of the Association of Independent Electronic Media and visiting professor on School of Journalism in Novi Sad, Serbia. He teaches television production and technical management in television. He received BSc degree in Telecommunications from the Faculty of Electronic Engineering in Nis, Serbia. 